\title{
Determination of Physicochemical Characteristics of Early Rain Water in a Rain Forest Region, Owerri, Nigeria.
}

C.I.A. Nwoko ${ }^{1}$, U.U. Egereonu ${ }^{1}$, L.N. Ukiwe ${ }^{1}$, U.L. Onu ${ }^{1}$ and E. Chinemerem ${ }^{1}$

${ }^{1}$ Department of Chemistry, Federal University of Technology, PMB 1526, Owerri, Nigeria

Corresponding author: nwokochristopher@yahoo.com

\begin{abstract}
Analysis of physicochemical characteristics of samples of rain water collected from rain gauges at two sampling stations at Orji and Umuchima-Ihiagwa in Owerri, Nigeria revealed that rain water from sampling station, Orji (RWSO) had the highest $\mathrm{pH}$ value (6.24), while values obtained for total suspended solids (14.23 mg/l), total dissolved solids (15.10 mg/l), calcium hardness $(3.91 \mathrm{mg} / \mathrm{l})$, and sulphate $(11.23 \mathrm{mg} / \mathrm{l})$ were highest for RWSO compared to values obtained from analysis of rain water sampling station, Umuchima (RWSU). However, it was observed that values obtained from nitrate analysis were almost equal $(0.62,0.60 \mathrm{mg} / \mathrm{l}$ for RWSO and RWSU) for both sampling stations, but values obtained for the physicochemical parameters from both sampling stations were within World Health Organization (WHO) permissible standards for quality drinking-water.
\end{abstract}

\section{Indexing terms/Keywords}

Calcium; nitrate; pollutants; rainwater; sulphate; sampling.

\section{Academic Discipline And Sub-Disciplines}

Environmental chemistry

\section{SUBJECT CLASSIFICATION}

Chemistry

\section{TYPE (METHOD/APPROACH)}

\section{Experimental}

\section{Council for Innovative Research}

Peer Review Research Publishing System

Journal: Journal of Advances in Chemistry

\author{
Vol. 10, No. 4 \\ editorjaconline@gmail.com
}




\subsection{INTRODUCTION}

Rainwater dissolves the gases of the atmosphere and contains particulates of dust and smoke. It runs over ground into streams, acquiring turbidity, taste and odor. When it seeps through the top soil, it dissolves carbon (iv) oxide produced by bacterial decomposition of organic matter in the top soil, thereby particles can coalesce on collision depending on their terminal velocity. The introduction of heavy metallic pollutant into the environment can occur in dissolved form as hydroxides, carbonates, sulphates, nitrates, phosphate and other minerals. In particulate form, associated with suspended matter, the pollutant can under favorable hydraulic conditions, be deposited on river beds [1-3]. Various types of pollutants exist and these include dust particles as a result of harmattan wind, and mist fumes, ash, soluble salts, fungi, sulphur (iv) oxide, nitrogen (iv) oxide, phosphorus (v) oxide, chloro-flourocarbon (CFC) and ammonia. The above gases are removed from the atmosphere by rainout and washout $[1,4$,$] . Some of these pollutants are classified as hazardous, meaning that$ they are flammable, corrosive, explosive or toxic.

As rainwater percolates through the soil, it can carry pollutants to the water table. Here they mix with groundwater and contaminates groundwater supply. Because groundwater movement is usually slow, polluted water may go undetected for a long time. However, most contamination is discovered only after the water has been consumed by humans and people start to fall sick [2]. Rain absorbs contaminants as it falls through the air, or drains from urban areas and farmland [7]. The atmosphere is made up of the troposphere, stratosphere, mesosphere and thermosphere. Substances may be removed from the atmosphere by precipitation in one of two ways, i.e., rainout or washout. Rainout occurs within the clouds where the most important process is condensation of water vapor on solid aerosol. Washout occurs below the clouds and is very efficient for the removal of large solid aerosol $[1,4]$. Both carbon monoxide and carbon (iv) oxide which are carbon related compounds are sent into the atmosphere by incomplete and complete combustion, respectively. Atmospheric source of this carbon monoxide is from the oxidation of methane. This is of a natural source since all the methane in the atmosphere are produced by the aerobic decomposition of organic matter. Carbon (iv) oxide which is a green house gas absorbs infrared radiation emitted from the surface of the earth by trapping some of these radiations and preventing them from escaping into space with the result that our planet is some $3^{\circ} \mathrm{C}$ warmer than it would otherwise be. Through fossil fuels, bush burning and other anthropogenic activities we are increasing the burden of carbon (iv) oxide. The atmospheric concentration of carbon (iv) oxide is reported to have increased from a pre-industrial value of 280 ppmv to more than 350 ppmv today at the rate of about 0.5 percent per year. When carbon (iv) oxide comes in contact with water the following occur.

$$
\mathrm{CO}_{2}+\mathrm{H}_{2} \mathrm{O}
$$$$
\mathrm{H}_{2} \mathrm{CO}_{3}
$$

Sulphur related compounds include $\mathrm{SO}_{2}$ and $\mathrm{SO}_{3}$ which cause acid rain. Rainwater usually has a pH of between 4-6. Fossil fuels which contain sulphur and its compounds on combustion release $\mathrm{SO}_{2}$ which on oxidation with ozone in the troposphere forms $\mathrm{SO}_{3}$. The $\mathrm{SO}_{3}$ dissolves in rainwater to form $\mathrm{H}_{2} \mathrm{SO}_{4}$ resulting in acid rain.

Nitrogen forms oxides corresponding to each of its known oxidation states. Of these oxides only dinitrogen oxide $\left(\mathrm{N}_{2} \mathrm{O}\right)$, nitrogen monoxide (NO) and nitrogen (iv) oxide appear as measurable quantities in the atmosphere. The most important reaction known as photochemical smog is characterized by a haze, ozone formation, eye irritation and damage to vegetation. Nitrate is released into the atmosphere initially as nitrogen (iv) oxide from gas flaring, biomass burning and fossil fuel combustion $[8,9]$.

The objective of this research was to investigate the concentration of some aerosols in the environment with a view to highlight the effect or otherwise consequences and sources of these elemental pollutants.

\subsection{Materials and Method}

\section{1 Sample collection, treatment, and analyses.}

Owerri the capital of Imo State is located on the eastern part of the Niger Delta between latitude $3^{0}$ and $6^{\circ} \mathrm{N}$ and longitude $5^{0}$ and $8^{0} \mathrm{E}$. Niger Delta is the largest Delta in Africa with a total area of about $7500 \mathrm{~km}[10,11]$. The annual rainfall for the area is about $2,000 \mathrm{~mm}$, while temperature ranges between 23 to $35^{\circ} \mathrm{C}$. Human settlement and activities in the towns have reduced the forest coverage. The geology of the Niger Delta in which Imo State is part has been described [10-12]. The geology is of the Benin formation.

The water samples were collected from the month of February to June 2009 in order to obtain the trend of the concentration of ions in the atmosphere. Weekly, rainwater samples (RWS) were collected from raingauges positioned at two stations Orji in Owerri and Umuchima in Iheagwa where the Federal University of Technology, Owerri is situated both in Imo State, Nigeria as shown in Fig.1. The measured rainwater sample (RWS) was shaken to ensure homogeneity, filtered and stored in labeled sample bottles with the following information: date of sampling, amount of rainfall and the location.

\subsection{Physicochemical analyses}

$\mathrm{pH}$ measurement was done using a pH meter (PHS 25), while electrical conductivity was carried out using a conductivity meter (model 1152, Emcee Electronics). However, total hardness was estimated by titrimetry, total suspended solid, total dissolved solids, and calcium and magnesium hardness were all analyzed by method described by [13-16]. Nitrate and sulphate were determined using a Pye Unicam visible spectrophotometer (model CE 7200), but iron (Fe) concentration was determined using an Atomic Absorption Spectrophotometer (AAS), (Perkin-Elmer model 214). 


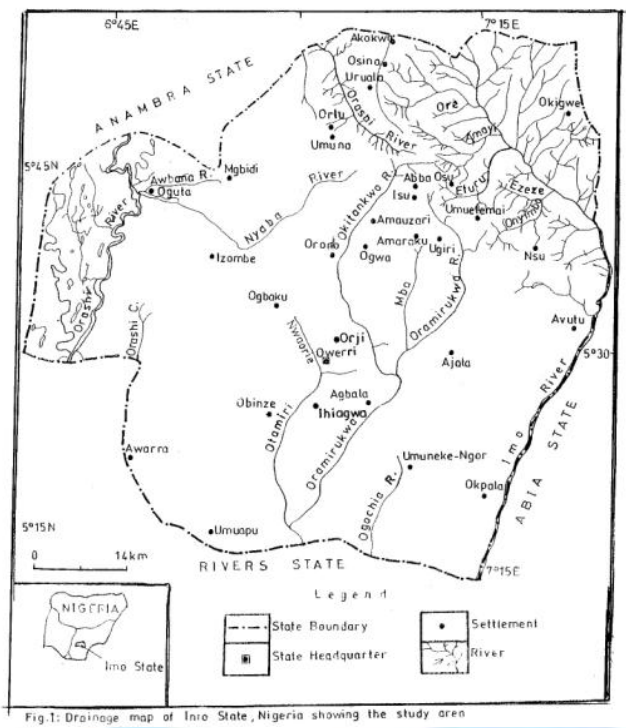

\subsection{Results and Discussion}

\section{Table 1: Physicochemical data of rainwater from Orii sampling station}

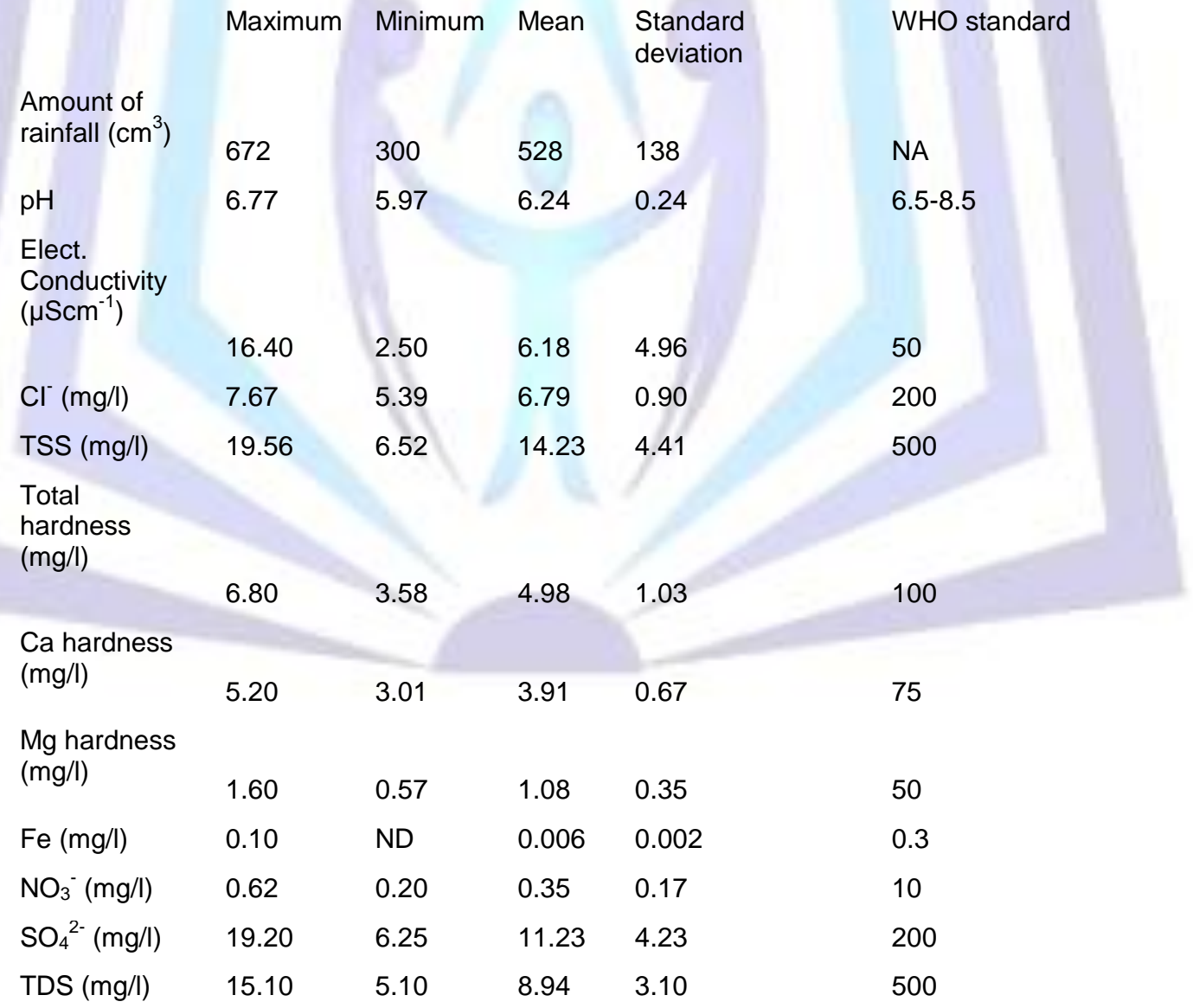

ND=Not Detected; NA=Not Applicable 
Table 2: Physicochemical data of rainwater from Umuchima-lhiagwa sampling station

Maximum Minimum Mean $\begin{aligned} & \text { Standard } \\ & \text { deviation }\end{aligned}$

Amount of rainfall $\left(\mathrm{cm}^{3}\right)$ 700 330 526

124

NA

$\mathrm{pH}$

5.34

5.40

0.22

6.5-8.5

Elect.

Conductivity

$\left(\mu \mathrm{Scm}^{-1}\right)$

$\begin{array}{llllll} & 17.90 & 3.85 & 7.74 & 5.39 & 50 \\ \mathrm{Cl}^{-}(\mathrm{mg} / \mathrm{l}) & 8.52 & 5.34 & 5.44 & 1.06 & 200 \\ \mathrm{TSS}(\mathrm{mg} / \mathrm{l}) & 18.76 & 4.50 & 11.99 & 4.78 & 500\end{array}$

Total

hardness

(mg/l)

Ca hardness

(mg/l)

3.56
2.50
0.66
$N D$
0.18
2.86
3.00

0.97

100

0.72

75

Mg hardness

(mg/l)

1.90

Fe (mg/l)

0.026

$\mathrm{NO}_{3}{ }^{-}(\mathrm{mg} / \mathrm{l})$

0.60

$\mathrm{SO}_{4}{ }^{2-}(\mathrm{mg} / \mathrm{l})$

18.52

TDS (mg/l)

12.00

3.00

1.48

0.65

0.010

0.004

0.36

0.14

8.87

5.44

7.20

2.95

75
50
0.3
10
200
500

ND=Not Detected; NA=Not Applicable

Nitrate and sulphate have their origin from fossil fuel combustion, automobile emissions and gas flaring. With increased anthropogenic activities in the urban areas they dissolve in rain drops and fall as acid rain. Acid rain has an adverse effect on the ecosystem, damaging vegetation and killing sea creatures. Nitrate concentration increased with urbanization resulting in rainwater sample from Orji-Owerri (RWSO) having higher concentration than rainwater sample from Umuchima-Ihiagwa (RWSU). These values decreased with the frequency of rainfall. For Orji-Oweri rainwater, nitrate concentration in the rainwater ranges between $0.62-0.20 \mathrm{mgl}^{-1}$, while Umucima-Ihiagwa nitrate concentration ranges between $0.60-0.18 \mathrm{mgl}^{-1}$. Oxides of nitrogen are primary pollutant which react in the atmosphere to form trioxonitrate (v) acid. This can affect the reactive nitrogen nutrients in the soil and ecosystem.

$$
4 \mathrm{NO}_{2}+2 \mathrm{H}_{2} \mathrm{O}+\mathrm{O}_{2} \longrightarrow 4 \mathrm{HNO}_{3}
$$

The minima, maxima, mean, and standard deviation values as well as WHO standard for the various parameters determined are shown in Tables 1 and 2. The values obtained in the present study were within the prevailing WHO permissible limits. For iron in RWSO the concentration ranges between ND to $0.010 \mathrm{mgl}^{-1}$, while for RWSU the iron concentration ranges from ND to $0.026 \mathrm{mgl}^{-1}$. This was far below the WHO standard for potable water, thus, depicting a level of awareness of environmental sanitation in the study area. The $\mathrm{pH}$ of rainwater in both areas is slightly acidic with mean values of 6.24 and 5.44 for Orji and Umuchima-Ihiagwa sampling station, respectively, and standard deviation of 0.24 and 0.22 from the mean respectively for Orji-Owerri and Ihiagwa. The Lowest pH value was 5.97 for RWSO. The acidity of the rainwater could be attributed to anthropogenic activities like industrial effluents, automobile emissions and bush burning. The electrical conductivity (E.C) in the two study areas range between 2.50 to $16.40 \mu \mathrm{Scm}^{-1}$ for Orji and between $3.85-17.90 \mu \mathrm{Scm}^{-1}$ for Ihiagwa, respectively. There is a diagonal relationship between EC and $\mathrm{pH}$. As EC increases $\mathrm{pH}$ decreases and vice-versa. This is as a result of dissolved ions in the rain water. Chloride concentration in RWSO and RWSU ranges from 5.39-7.67 mgl to $4.82-8.52 \mathrm{mgl}^{-1}$, respectively. Chloride ions in very small concentration can cause active corrosion. The total dissolved solids (TDS) values in the study area range between 5.10-15.10 $\mathrm{mgl}^{-1}$ for RWSO, and 3.00-12.00 $\mathrm{mgl}^{-1}$ for RWSU, respectively. Both TDS values are within the WHO standard of $500 \mathrm{mgl}^{-1}$ for potable water. The highest TDS value was obtained from Orji-Owerri while the lowest was from Umuchima-Ihiagwa.

The total suspended solids (TSS) ranges from $6.52-19.5 \mathrm{mgl}^{-1}$ for RWSO, while that for RWSU ranged between 4.50 to $18.76 \mathrm{mgl}^{-1}$. The TSS value was higher in RWSO than in RWSU, this could be attributed to more anthropogenic activities. The TSS depicts solid particles in the atmosphere that were not able to dissolve in the rainwater. This could lead to health hazard such as liver, asthma and respiratory problems in man [9]. Total hardness was detected in both RWSO and 
RWSU, with hardness values ranging between 6.40-6.80 $\mathrm{mgl}^{-1}$, and between 3.56-6.40 $\mathrm{mgl}^{-1}$ for RWSU. Higher values of hardness were obtained for RWSO than for RWSU. Calcium and magnesium salts are responsible for hardness in water. Hardness of water spoil fabrics, cause chocking and clogging troubles in pipelines, and also cause formation of scales in electric boilers leading to wastage of fuel and the danger of boilers overheating.

\subsection{Conclusion}

Analysis of rainwater from the sampled stations revealed the presence of some notable pollutants in RWSO and RWSU. lons detected in these samples were within $\mathrm{WHO}$ standard. The $\mathrm{pH}$ which could increase with the frequency of rainfall, in the present study, fell within WHO permissible limit of 6.00-8.50 for potable water. Also other parameters of interest analyzed were within WHO permissible limit for quality drinking-water. The present study has revealed that human activities such as automobile emission, fossil fuel combustion, industrial effluents, bush burning, wind-blown dust, and agrochemicals didn't affect the rain water from these stations adversely. However, reduction in some of these activities could further reduce possible environmental pollution of the sample area.

\section{References}

1. U.U. Egereonu (2006). Physicochemical assessment of rainwater from two raingauged stations in the rainforest region, Anambra State, Nigeria. J. Chem. Soc. Nigeria, 30, 43-48.

2. U.U. Egereonu (2004a). Assessment of atmospheric aerosols from three satellite sations: Heavy metal pollutants, J. AMSE, 65, 71-87.

3. C. A. Hampel and G.G.Hawley (1987). The Encyclopaedia of Chemistry, $3^{\text {rd }}$ Ed; Library of Congress Cataloguing in Publication Data, 11-59.

4. D. J. Speeding (1997). Air Pollution, $2^{\text {nd }}$ Edn., Clarendon Press, Oxford, pp. 17-30.

5. J. T. Ayodele and M.B. Abubakar (1998). Trace elements contamination of rainwater in the semi-arid region of Kano, Nigeria. J Environmental Management and Health, 9,180.

6. U. U.Egereonu (2004b). Comparative analysis of Nembe Light and Bonny Medium crude oil of Nigeria and their associated water. J. AMSE, 65, 23-32.

7. U. U. Egereonu and R. Dike (2007). Evalution of the pollution levels of Orashi River and Oguta Lake water. J. Chem. Soc. Nigeria, 32,159-166.

8. D. Dignon, J. E. Penner, C. S. Atherton, and J. J. Walton (1991). Atmospheric Reactive Nitrogen- a Model Study of Natural and Anthropogenic Sources and the Role of Microbial and Soil Emission, Available [Online]; http://agu.org/1999/d900801,

9. R. Arimoto, R. A. Duce, B. J. Ray, J. D. Cullen and J. M. Merill (1991). Trace Elements in the Atmosphere Over the North Atlantic. Available [Online]; http://agu.org/1999/d900801,

10. S. W. Peter (1991). Outline of regional geology of Africa. Earth Science, 40, 134-150.

11. U. U. Egereonu and D. Emeziem (2006). Physicochemical analysis of selected groundwater in Rivers State, Nigeria, to ascertain pollution level, encrustation and corrosion potentials. J. Chem. Soc Nigeria, 31, 141 146.

12. U. U. Egereonu and E.Odumegwu (2006). Selected groundwater investigation in Cross-River State of Nigeria for encrustation and corrosion characteristics. J. Chem. Soc. Nigeria, 31, 168-175.

13. M. A. Franson (1995). Standard Methods for the examination of Water and Wastewater, $14^{\text {th }}$ Ed; APHA-AWAWPCF, NY, pp.150-162, 235 \& 252.

14. IITA (1990). Selected Method for Soils and Plant Analysis,IITA Technical Bulletin 30, Ibadan, p. 6.

15 A. I. Vogel (1989). A Textbook of Inorganic Analysis, $3^{\text {rd }}$ Ed; Longman, London, p256.

$16 \mathrm{HACH}$ (1983). Water Analysis Handbook, Loveland, $3^{\text {rd }}$., Edn., Colorado, pp. 181-278. 